\title{
Factors associated with the quality of life of caregivers of children and adolescents with chronic conditions
}

\author{
Fatores associados à qualidade de vida de cuidadores \\ de crianças e adolescentes com condições crônicas \\ Factores associados a la calidad de vida de los cuidadores \\ de niños y adolescentes con enfermedades crónicas
}

\author{
Érika Leite da Silva Cardoso ${ }^{a}$ \\ Sérgio Ribeiro dos Santos ${ }^{a}$ \\ Yana Balduíno de Araújob \\ Nívea Trindade de Araújo Tiburtino Neves ${ }^{a}$ \\ João Agnaldo do Nascimento ${ }^{a}$
}

\section{How to cite this article: Cardoso ELS, Santos SR, Araújo YB, Neves NTAT, Nascimento JA. Factors associated with the quality of life of caregivers of children and adolescents with chronic conditions. Rev Gaúcha Enferm. 2021;42:e20190318. doi: https://doi. org/10.1590/1983-1447.2021.20190318}

aniversidade Federal da Paraíba (UFPB). João Pessoa, Paraíba, Brasil.

Faculdade de Medicina Nova Esperança (FAMENE). João Pessoa, Paraíba, Brasil.

\section{ABSTRACT}

Objective: To evaluate the quality of life and associated factors in caregivers of children and adolescents with chronic conditions. Method: Cross-sectional study, developed with data from the Children Information System of Adolescents with Chronic Diseases. The sample consisted of 143 caregivers. Data collection took place between August and October 2018. For data analysis, chi-square statistics and Binary Logistic Regression were used.

Results: Through the study it was possible to identify that the variables that had impact on the low quality of life of the caregiver were: greater number of children with chronic conditions, routine use of medication, and financial limitations, which were considered risk factors. In turn, owning a home and having emotional support were protective factors.

Conclusion: It was observed that the caregivers had low quality of life, and knowledge of the factors that contribute to this may enable an outstanding care to the caregiver.

Keywords: Caregivers. Quality of life. Chronic disease. Child. Adolescent.

\section{RESUMO}

Objetivo: Avaliar a qualidade de vida e fatores associados de cuidadores de crianças e adolescentes com condições crônicas. Método: Estudo transversal, desenvolvido com dados do Sistema de Informação de Crianças de Adolescentes com Doenças Crônicas. A amostra foi composta por 143 cuidadores. A coleta de dados ocorreu entre agosto e outubro de 2018. Para análise dos dados utilizou-se a estatística qui-quadrado e a Regressão Logística Binária.

Resultados: Com o estudo foi possível identificar que as variáveis que possuíam impacto sobre a baixa qualidade de vida do cuidador foram: maior número de filhos com condições crônicas, uso rotineiro de medicamentos e limitação financeira, as quais foram consideradas fatores de risco. Por sua vez, possuir casa própria e ter apoio emocional consistiram em fatores de proteção.

Conclusão: Observou-se que os cuidadores possuíam qualidade de vida baixa e o conhecimento dos fatores que contribuem para isso poderá possibilitar um cuidado diferenciado ao cuidador.

Palavras-chave: Cuidadores. Qualidade de vida. Doença crônica. Criança. Adolescente.

\section{RESUMEN}

Objetivo: Evaluar la calidad de vida y los factores asociados de los cuidadores de niños y adolescentes con afecciones crónicas, Método: Estudio transversal, desarrollado con datos del Sistema de Información Infantil de Adolescentes con Enfermedades Crónicas. La muestra consistió en 143 cuidadores. La recolección de datos tuvo lugar entre agosto y octubre de 2018. Para el análisis de datos, se utilizó estadísticas de chi-cuadrado y regresión logística binaria.

Resultados: El estudio posibilitó identificar que las variables que tuvieron un impacto en la baja calidad de vida del cuidador fueron: mayor número de niños con afecciones crónicas, uso rutinario de medicamentos y limitaciones financieras, que se consideró como factores de riesgo. A su vez, ser propietario de una casa y tener apoyo emocional eran factores protectores.

Conclusión: Se observó que los cuidadores tenían baja calidad de vida y el conocimiento de los factores que contribuyen a esto puede permitir una atención especial para el cuidador.

Palabras clave: Cuidadores. Calidad de vida. Enfermedad crónica. Niño. Adolescente. 


\section{口INTRODUCTION}

Chronic conditions are health problems that require continuous follow up for a long period of time. This definition is broad, including from chronic noncommunicable diseases to persistent communicable ones. In addition, long-term mental disorders are also chronic conditions, as are physical deficiencies and structural disabilities ${ }^{(1)}$.

During childhood and adolescence, chronic conditions cause unavoidable changes in the lives of the person with the disease and their family. Hospitalizations, special care, and the need to be always under multidisciplinary follow up, lead families to spend much more than time, since they also need to reorganize their finances and daily life activities ${ }^{(2-3)}$.

As a result, to take care of their new life routine, some member of the family must adapt their lives to attend to the needs associated to the chronic condition. Thus, the role of the main caregiver emerges ${ }^{(4)}$. This is the person that assumes the greatest part of care and, therefore, is the one affected the most, since they need to abdicate from daily life activities, such as their job, study, and leisure, to dedicate to the demands of care ${ }^{(5-7)}$.

Generally, the main caregiver tends to be the mother of the child or adolescent who has a chronic condition. She is the one who takes upon herself the care of her child, since, culturally, care is a role attributed to women ${ }^{(8)}$. However, in addition to dedicating to care, the mother also is responsible for caring for the house and the other children and members of the family, leading to an overload and, therefore, to an exhausting situation, that impairs their quality of life $\mathrm{e}^{(9)}$.

As a result, caregivers are impacted in many different aspects of their lives: financial, occupational, personal, and intra- and/or extra-familial relations ${ }^{(10)}$. Due to this reality, the act of caring may be experienced with a certain level of suffering and difficulty, affecting the caregiver in several aspects, such as: psychological, physical, social, and familial ${ }^{(11)}$.

This is why studies ${ }^{(12-13)}$ have pointed out that chronic conditions are triggers for high levels of stress among caregivers. As a result, one of the costs of care is the impairment of the health of the caregiver, and, thus, many types of support are essential for an effective confrontation of the chronic condition. Among these, there are maternal, emotional, informational, financial, and spiritual support ${ }^{(10,14)}$.

Considering the context experienced by the caregiver, it is possible to identify how much these changes and life contexts impact their quality of life, since understanding this reality may favor the elaboration of strategies that allow for a better care to caregivers, strengthening them and contributing for them to have the resources they need to offer an appropriate support to the child/adolescent with a chronic condition.

Therefore, the following question was elaborated to guide this research: What are the factors associated to the quality of life of caregivers of children and adolescents with chronic conditions? To answer this question, this study aimed to evaluate the quality of life and its associated factors in caregivers of children and adolescents with chronic conditions.

\section{METHODS}

This is an analytical, quantitative, cross-sectional and descriptive-explanatory research. The data used to develop this study was obtained from the database of the Information System of Children and Adolescents with Chronic Diseases (SICADC), software that belongs to a research group from the Universidade Federal da Paraíba (UFPB), which is used in reference hospitals in the city of João Pessoa and was elaborated using a validated instrument ${ }^{(15)}$. This system is fed with information of children and adolescents with chronic conditions, who are receiving outpatient treatment or hospitalized. Its data was accessed after a Concession for Data Usage was requested.

In the SICADC, the records of a child or adolescent with a chronic condition are created in eight stages: data collection, identification of the child or adolescent, identification of the main caregiver, social and sanitary data, data on the disease and its treatment, data on the current hospitalization, service network, and family dynamic. Therefore, considering that the SICADC not only maintains records on children and adolescents with chronic conditions, but also on their main caregivers, the target population of this study was made up by all caregivers of children and adolescents in the system.

The system has 300 children and adolescents registered, all of whom were placed in the system from August 2015 to August 2018. From these, 20 adolescents were above 18 years of age, that is, were in transition to adult age, while 18 children/adolescents were registered in the system as deceased, thus being excluded from the calculation of the sample size. As a result, the accessible population was made up by 262 caregivers. Therefore, with a confidence level of $95 \%$ and an error of 5\%, a sample of 143 caregivers was determined.

The inclusion criteria considered caregivers that could be found in the address present in the records, or those who had an active phone number, for the interviews to be scheduled in places suggested by them. The exclusion criteria were the 
caregivers of children and adolescents who died during the study, whose death was still absent from the system.

Data collection was carried out from August to October 2018, and took place as follows: after selecting a caregiver who was registered at SICADC, the researcher contacted the caregivers to apply a generic quality of life assessment instrument, the World Health Organization Quality of Life, brief version (WHOQOL-Bref). This instrument, validated in Portuguese ${ }^{(16)}$, has four domains: physical, psychological, social relations, and environment. It includes 26 questions, two of which are general quality of life questions, while the others represent each of the 24 facets that make it up.

The answers to the instrument are scored according to a 5-point Likert scale, from 1 to 5. The scores of the domains are calculated through the sum of the scores of the mean of the " $n$ "questions that make up each domain. Then, the scores of the domains are converted into a scale that goes from 0 to 100, which are scaled in a positive direction. Consequently, the higher the score, the higher the quality of life.

Later, the results of this measurement of quality of life were evaluated together with the information made available at the SICADC. After collection, data was tabulated in an electronic spreadsheet, and later analyzed using the statistical software Statistical Package for Social Sciences (SPSS), version 20.0.

For data analysis, descriptive statistics and inference methods were used, such as the chi-squared test ( $\chi 2)$, Cronbach's alpha, and the binary logistic regression model. In this study, the event of interest was the quality of life of the caregivers of children and adolescent with chronic conditions, a variable that was found through the mean of WHOQOL-Bref domain scores. Through statistical analysis, the analysis sought to identify, using the data available in the SICADC, the sociodemographic, disease, treatment, and family dynamic factors that could predict this outcome.

The binary logistic regression was developed with a 0.10 significance level (a). Considering that the quality of life is measured through scores (variable and continuous), and that the binary logistic regression requires the outcome to be binary, this variable was made into a dichotomy for the purpose of this analysis. In literature, there is no parameter that indicates a high or low quality of life. Therefore, to dichotomize the main variable, the median of the scores found in the study was chosen as the parameter.

Therefore, all caregivers with scores above the median were classified as having a high quality of life. In turn, those whose scores were below the median were classified as a having a low quality of life. It stands out that the dependent variables were found through the SICADC, and the variables included in the regression model were selected from the chi-squared association test, considering a 0.10 significance level (a), to obtain a higher number of factors that could be associated to the outcome studied.

This study was evaluated and approved by the Research Ethics Committee/Plataforma Brasil from the Health Sciences Center of the Universidade Federal da Paraíba under opinion 2.778.334 and CAAE 92321518.8.0000.5188, and was in accordance with the Directives and Norms for Researches with Human Beings, which are prescribed in Resolution No. 466/12 from the National Council of Health.

\section{RESULTS}

The profile of children and adolescents in this study found that most were female (53.8\%), brown-skinned (51.7\%), from 0 to 5 years old (35.7\%) and from 13 to 18 years old (35.7\%). Most attended school (69.9\%) and, from these, $40 \%$ were in elementary school. In the sample, 49 (34.3\%) of the children and adolescents had some type of deficiency, especially physical (13.3\%), motor (14\%), and cognitive deficiency (15.4\%).

Regarding the profile of the caregivers, it was found that most were female (98.6\%), and, among these, $90.9 \%$ were the mothers. Most caregivers were brown-skinned (60.1\%), from 31 to 49 years old (64.3\%), married (35.7\%), and had more than 2 children (50.3\%). 20 caregivers, a significant number (14\%), had more than 1 child with some form of chronic diagnostic, which increases the overload of care and concern.

From the 143 caregivers, 93 (65\%) were unemployed, and many justified their unemployment due to the time requirements of caring for the child/adolescent who had the chronic disease. Furthermore, 33.6\% had elementary education as their educational level. Regarding whether they had any type of illness, 45 (31.5\%) of caregivers stated to have some illness, especially hypertension and diabetes. 39 (27.3\%) caregivers stated to routinely use some type of medication, for medical treatment.

The analysis of the quality of life of caregivers was carried out through the WHOQOL-Bref. However, before the scores from the instrument were verified, its internal consistency in the particular case of the target audience for this study was evaluated. To do so, Cronbach's Alpha coefficient was calculated, resulting in 0.86. According to Cronbach's Alpha reliability assessment, this result represents high reliability, and, therefore, the instrument was found to be adequate to measure what it was aimed to measure.

The scores of each WHOQOL-Bref domain were calculated through the sum of the scores of each item from each specific domain, which were then linearly converted into a scale from 0 to 100 . Therefore, a score of 0 indicates the lowest quality of life, while 100 indicates the highest. Table 1 indicates the 
central tendency measures of the WHOQOL-Bref domains, as well as the total score of quality of life.

The highest scores were found in the physical and psychological domains. The lowest ones, in turn, were found in the environment domain, followed by the social relations domains, that is, the domains that were impaired the most in the study.

The total quality of life score, which made up the main variable of the study, was calculated from the mean of the four domains of the instrument. Then, the descriptive means were calculated. The mean of the quality-of-life score was 58.88 , with a standard deviation of 13.70 and a variation coefficient of $23 \%$. This coefficient indicates that the variability is a bit high with regard to the mean, indicating that, in this case, the median, 61 , is the most representative central tendency measure.

Therefore, taking into consideration the median as the total score of the quality of life, the sample was divided in two groups. All caregivers whose total quality of life scores were above the median were classified as having a high quality of life, while all those whose quality of life was below the median were classified as having a low quality of life. As a result, from the 143 caregivers of children and adolescents with chronic conditions, 69 (48.3\%) had a high quality of life and 74 (51.7\%) had a low quality of life.

After evaluating the quality-of-life scores, and dividing the sample in two groups, considering the median of the total score for the quality of life, there was an attempt to verify which variables from the SICADC were associated to the variable total score of quality of life. To do so, all variables were dichotomized and tested using the chi-squared test. The result of the variables that were significant can be found in table 2.

The independent variables used in the model of logistic regression were those that the chi-squared test indicated that were associated to the main variable total score of quality of life. In the binary logistic regression, the dependent variable is known to assume only two values: 0 and 1. The result of 1 is the characteristic of interest for the regression.

Considering that 74 (51.7\%) of caregivers were classified as having a low quality of life, this characteristic was found to be the characteristic of interest to this regression. Therefore, this study attempted to verify the independent variables that could predict when the caregiver would present a low quality of life. After this was determined, the binary logistic regression was carried out.

The first test to validate the regression model is the Omnibus Test, which tests the null hypothesis according to which all coefficients are equal to zero. In this study, this hypothesis was rejected ( $p$-value $=0.000$ ), meaning that at least one regression coefficient is different from zero. Therefore, all explanatory variables used in the model may calculate the probability of a low quality of life.

Table 1 - Descriptive measures of the WHOQOL-Bref domains - Brazil - 2019

\begin{tabular}{lccccc}
$\begin{array}{l}\text { Central Tendency } \\
\text { Measures }\end{array}$ & $\begin{array}{c}\text { Physical } \\
\text { Domain }\end{array}$ & $\begin{array}{c}\text { Psychological } \\
\text { Domain }\end{array}$ & $\begin{array}{c}\text { Social } \\
\text { Relations Domain }\end{array}$ & $\begin{array}{c}\text { Environment } \\
\text { Domain }\end{array}$ & $\begin{array}{c}\text { Total Quality } \\
\text { of Life Score }\end{array}$ \\
\hline Mean & 62.96 & 60.67 & 60.10 & 49.00 & 58.33 \\
Standard deviation & 17.47 & 18.87 & 19.97 & 13.90 & 13.70 \\
Variance & 305.17 & 356.22 & 398.59 & 193.28 & 187.71 \\
Variance Coefficient & 0.27 & 0.31 & 0.33 & 0.28 & 0.23 \\
Median & 63 & 63 & 56 & 50 & 61 \\
Minimum & 19 & 6 & 0 & 25 & 23.75 \\
Maximum & 100 & 94 & 100 & 81 & 89.25 \\
\hline
\end{tabular}

Source: Research Data, 2019. 
Table 2 - Relation of variables that were associated to the variable total score of quality of life, according to the chi-squared test - Brazil - 2019

\begin{tabular}{|c|c|c|}
\hline Variables & p-value & $\chi^{2}$ value ${ }^{*}$ \\
\hline $\begin{array}{l}\text { Number of children with chronic conditions } \\
\text { ( } 1 \text { child/2 or more children) }\end{array}$ & 0.006 & 7.433 \\
\hline Does the caregiver have any diseases? (Yes/No) & 0.002 & 9.859 \\
\hline Does the caregiver use any medication routinely? (Yes/No) & 0.003 & 8.631 \\
\hline $\begin{array}{l}\text { Housing situation } \\
\text { (Owns a house/Does not own a house) }\end{array}$ & 0.081 & 3.046 \\
\hline $\begin{array}{l}\text { Child/adolescent has any restrictions due to the } \\
\text { diagnostic? (Yes/No) }\end{array}$ & 0.035 & 4.439 \\
\hline Are other family members involved in care? (Yes/No) & 0.029 & 4.739 \\
\hline Does the caregiver receive emotional support? (Yes/No) & 0.057 & 3.630 \\
\hline $\begin{array}{l}\text { Were there limitations in the routine of the Family after the } \\
\text { child/adolescent was diagnosed? (Yes/No) }\end{array}$ & 0.067 & 3.343 \\
\hline $\begin{array}{l}\text { Were there Financial limitations after the chronic } \\
\text { condition? (Yes/No) }\end{array}$ & 0.047 & 3.959 \\
\hline
\end{tabular}

Source: Research Data, 2019.

Note: * Chi-squared test. Significance level of 0.10

The Hosmer and Lemeshow test was also used to calculate the goodness of fit, that is, to verify whether the model suggested could explain what was observed. Therefore, in this study, the null hypothesis, according to which there are no significant differences between the values predicted and those found was accepted ( $p$-value $=0.463$ ). Finally, the result of the calculation of the likelihood ratio of the binary logistic regression model was $63.6 \%$.

After the significance of the tests of model adjustment was verified, the regression itself could be evaluated. The variables that were associated to the "total score of the quality of life" were included in the model, and adjusted using, as a parameter, the p-value and Wald's test. After this process, the following adjustment of the logistic regression was made, as shown in table 3 .

Through the regression, the odds ratio of each variable could be obtained, and is presented in table 3 by Exp. ( $\beta$ ), since, in the regression, the odds ratio is calculated through the exponentiation of the variable under study. An odds ratio above 1 indicates a risk factor; below 1, it indicates a protective factor. Values of 1 , in turn, indicate no association.

According to the model of logistic regression, the following variables were significant, meaning they had an impact over the quality of life of the caregiver:

Number of children with chronic conditions ( $p$-value $=0.059$ ): the odds ratio of this variable was 3.232 $(\mathrm{Cl}=1.163 ; 8.983)$. This means that caregivers with 2 or more children, affected by a chronic condition, are 3 times more likely to have a low quality of life.

\section{Does the caregiver use any medication routinely?}

( $p$-value $=0.003$ ): this variable refers to the caregivers that use medication routinely, to treat some disease. These caregivers were found to have an odds ratio of $3.868(\mathrm{Cl}=1.840 ; 8.133)$, meaning that caregivers with some pathology are 3 times more likely to have a low quality of life. 
Table 3 - Results of the final adjustment of the binary logistic regression - Brazil - 2019

\begin{tabular}{|c|c|c|c|c|c|c|c|}
\hline \multirow[t]{2}{*}{ Variables } & \multirow{2}{*}{$\begin{array}{c}\text { Coef.* } \\
\text { (ß) }\end{array}$} & \multirow{2}{*}{$\begin{array}{c}\text { Standard } \\
\text { Deviation } \\
\text { (ß) }\end{array}$} & \multirow{2}{*}{$\begin{array}{l}\text { Coef.* } \\
\text { Wald }\end{array}$} & \multirow[t]{2}{*}{ p-value } & \multirow[t]{2}{*}{ Exp. ( $\beta$ ) } & \multicolumn{2}{|c|}{$\begin{array}{c}\text { Confidence Interval } \\
\text { for Exp. ( } \beta) \\
90 \%\end{array}$} \\
\hline & & & & & & LL** & UL*** \\
\hline $\begin{array}{l}\text { Number of children with } \\
\text { chronic conditions ( } 1 \text { ) }\end{array}$ & 1.173 & 0.622 & 3.562 & 0.059 & 3.232 & 1.163 & 8.983 \\
\hline $\begin{array}{l}\text { Does the caregiver use any } \\
\text { medication routinely? (1) }\end{array}$ & 1.353 & 0.452 & 8.968 & 0.003 & 3.868 & 1.840 & 8.133 \\
\hline $\begin{array}{l}\text { Housing } \\
\text { situation (1) }\end{array}$ & -0.686 & 0.384 & 3.190 & 0.074 & 0.504 & 0.268 & 0.947 \\
\hline $\begin{array}{l}\text { Emotional } \\
\text { Support (1) }\end{array}$ & -0.763 & 0.384 & 3.955 & 0.047 & 0.466 & 0.248 & 0.876 \\
\hline $\begin{array}{l}\text { Financial limitations after } \\
\text { condition? (1) }\end{array}$ & 0.854 & 0.447 & 3.651 & 0.056 & 2.349 & 1.126 & 4.900 \\
\hline Constant & -0.163 & 0.522 & 0.098 & 0.754 & 0.849 & & \\
\hline
\end{tabular}

Source: Research Data, 2019.

Note: ${ }^{*}$ Coefficient. ${ }^{* *}$ Lower limit. ${ }^{* *}$ Upper limit.

Financial Limitations after the Chronic Condition of the Child/Adolescent $(p$-value $=0.056)$ : this variable presented an odds ratio of $2.349(\mathrm{Cl}=1.126 ; 4.900)$. That is, caregivers that go through financial limitations after the child/adolescent becomes chronically ill are 2 times more likely to have a low quality of life.

Housing Situation ( $p$-value $=0.074$ ): this variable presented an odds ratio of $0.504(\mathrm{Cl}=0.268 ; 0.947)$. Therefore, it can be inferred that caregivers who own their houses are less likely to have a low quality of life, since their housing situation is a protective factor for them.

Emotional Support ( $p$-value $=0.047$ ): the odds ratio of the emotional support was $0.466(\mathrm{Cl}=0.248 ; 0.876)$. Therefore, caregivers who have emotional support are less likely to have a low quality of life. Therefore, the emotional support is a protective factor for these individuals.

\section{DISCUSSION}

From the 143 caregivers of children and adolescents with chronic conditions, 69 (48.3\%) had a high quality of life, while
74 (51.7\%) had a low quality of life. That is, most people in the group being studied were below the median, meaning their quality of life was impaired due to the chronic conditions. Studies that compared groups to evaluate the quality of life have indicated that the scores of the domains of caregivers of children/adolescents with chronic diseases were inferior to those who care for healthy children/adolescents ${ }^{(11,13)}$. This corroborates, in a way, this study, according to which, within the group of caregivers of children/adolescents with chronic conditions, the classification of quality of life is low.

The results found here show that, among the domains of WHOQOL-Bref, the one with the lowest score was environment. This domain evaluates physical safety and protection, the home environment, financial resources, social and health care, opportunity of acquiring new information and ability, participation and opportunities for leisure, physical environment (pollution, climate, noise) and, finally, the means of transportation. Some studies ${ }^{(12,17-18)}$ that used the WHOQOL-Bref to evaluate the quality of life of caregivers of children/adolescents with chronic conditions also found that the environment domain was the most affected, corroborating the data from this research. 
Upon an evaluation of the findings of the logistic regression, according to its odds ratio, the number of children with chronic conditions was found to be a significant variable and a risk factor. It was found that caregivers who had 2 or more children with chronic conditions were 3 times more likely to have a low quality of life.

The authors of a study ${ }^{18}$ found that the more children the caregiver has, the lower her/his quality of life. This takes into consideration the number of children, regardless of their chronic health conditions. In this study, the impact is negative with regard to the quality of life of the caregiver when they have 2 or more children affected by chronic conditions, which makes the context even more serious. From the 20 caregivers found that experience this situation, $16(80 \%)$ had a low quality of life.

Another aspect that was significant in the logistic regression was related to the emotional support. According to the odds ratio of the regression, emotional support decreases the odds of low quality of life, being, thus, a protective factor. The emotional support, that must be constant and is essential for the caregiver to perceive themselves as capable and motivated to continue caring for the child ${ }^{(10)}$.

This support involves expressions of love, and is considered to be beneficial, since it gives relief to suffering. It is hard to cope with a chronic condition without this support. That is why it is important for the caregiver and child/adolescent to receive help from people who are seen as reliable, with whom they have an affective bond ${ }^{(19)}$, since this helps coping with the chronic condition in childhood and adolescence ${ }^{(3)}$.

The housing situation was also significant for the logistic regression. According to the odds ratio, owning a house diminishes the odds of the caregiver to have a low quality of life, also being, as a result, a protective factor. In this study, it was found that $33(61.1 \%)$ individuals, who did not own a house, presented a low quality of life.

Owning a house is a situation in which there are less expenses, since families that own houses do not need to be concerned about paying rent. In a study carried out with mothers of children who depend on the technology regarding medication care, the report of a caregiver stated that, sometimes, she needed to choose between buying medication for the child or paying rent ${ }^{(14)}$, showing that paying rent is another burden for these caregivers.

Many other aspects, in addition to the housing conditions, involve the caregivers of children/adolescents with chronic diseases and are associated to financial aspects. This study found that financial limitations about the chronic diagnosis of a child/adolescent, according to the odds ratio, make it twice more likely for a caregiver to have a low quality of life, making it, as expected, a risk factor.
The activity of caring for people with chronic conditions is related to intense daily journeys, leading the caregiver to abandon their professional activities and exclusively dedicate to treating the person being cared for and the domestic activities ${ }^{(20)}$. This abandonment of employment bonds leads to a series of frustrations and concerns among family members ${ }^{(9)}$, since the superinvestment of time and money in the care of the child, coupled with the lack of contribution to the house budget, means that the financial resources of the family are reduced, culminating in limitations that prejudice social participation, leisure activities, among others ${ }^{(20)}$, leading to emotional and psychological tear ${ }^{(21)}$.

That is why it is relevant for a source of social support to minimize the expenses of the family with regard to the challenges of care ${ }^{(19)}$, since giving support to their urgent needs is an important measure, that directly interferes in the quality of life of all members of the family. The financial resources offered by the State are also extremely important, since, in many families, they are the only source of income ${ }^{(3)}$.

Finally, according to the odds ratio of the regression, the use of medications by the caregiver was also significant and a risk factor, since it makes it 3 times more likely for caregivers to have a low quality of life. It stands out that, at this point, only caregivers who made use of medication continuously, as a medical treatment, were considered.

The use of medication by the caregiver is a variable that can be discussed together with the variable about diseases from the caregiver, considering how intimately they are related. Both, according to the chi-squared test, are associated to the outcome total quality of life. Therefore, when caregivers have a disease, and treat it, they, in a certain way, become vulnerable. However, when this reality is associated to the care of a child/adolescent with a chronic condition, it becomes more severe, and compromises the quality of life of this individual.

Therefore, the overload related to care makes the caregiver more likely to become ill, since they even neglect their own health to prioritize that of the person receiving care ${ }^{(4)}$. This happens, for many reasons, among which the lack of time, the impossibility of leaving the person being cared for alone, and tiredness ${ }^{(20)}$. This reality brings suffering to the caregiver, since they seek to hide their pain, to the detriment of the care, which may lead them to accumulate tension ${ }^{(15)}$, which, in turn, can lead their health condition to worsen.

Therefore, it can be found that, by dedicating to care for another, the caregivers forget to care for themselves, which, in a way, impairs their self-care. This is a well-documented reality ${ }^{(3,7)}$. In a study ${ }^{(7)}$, caregivers stated that, due to the many demands of care, they had less time and energy to dedicate 
to maintaining themselves and their family. This, sooner or later, leads to illness.

Considering all these aspects discussed, the caregiver is understood to need special attention, especially from health professionals, since care and the assistance offered cannot be restricted to children/adolescents, who, after all, are dependent on other people, and carry, silently, the load of care and its many consequences. Caregivers do so for love and due to the conviction that better days will come. However, they are human beings who are often overwhelmed by a simple need: that of venting, having someone who can listen to them, who can embrace them with no judgment. Therefore, those who care must be cared for, so they can care for others with more efficacy and effectiveness.

\section{$\square$ CONCLUSION}

Through this study, it was possible to evaluate the quality of life of caregivers of children and adolescents with chronic conditions, registered in the Information System of Children and Adolescents with Chronic Diseases, as well as to identify the factors related to their quality of life. It was found that most caregivers had a low quality of life, a reality that is impacted by factors such as: higher number of children with chronic conditions, routine use of medication by the caregiver, and financial limitations after the chronic conditions emerged, all of which were found to be risk factors. On the other hand, owning a house and receiving emotional support were found to be protective factors.

Therefore, the study brought peculiar and specific information that prove that, not only the child/adolescent with a chronic disease needs to receive attention, but the same is true for their caregiver, who is often put at the margin of the care offered by the health professionals. Therefore, one must be attentive to the mother-child dyad, and go beyond biological aspects, considering the biopsychosocial contexts in which the individual may be inserted. Therefore, knowing the factors that can affect the quality of life of caregivers, looking at the perspective of data analysis, will collaborate for the professionals to make decisions, helping them provide a more consistent assistance, directed at the real needs of this public.

In this context, the health services must implement practical measures of health education that are compatible with the reality experienced in the lives of these individuals. This study found that the emotional support is a protective factor with regard to the quality of life of the caregiver, meaning that this type of support mitigates the negative aspects of care. This is something simple, that can be done by health professionals and developed through qualified listening, or by the formation of groups of caregivers who experience the same reality, helping them cope with the chronic condition and its many implications.

More specifically, nurses, as members of a professional category whose main focus is care, must assist the individual as a whole, considering that the biological, psychological, and social aspects are all interconnected and interfere in the health of individuals. By knowing the factors that affect the quality of life of the caregivers of children and adolescents with chronic conditions, the nurse has the necessary information for the elaboration of caregiver plans that are increasingly directed and effective, which will contribute directly for the needs of caregivers and indirectly for the care they offer to children and adolescents with chronic conditions.

\section{STUDY LIMITATIONS}

Due to the sample size and to the fact that this is a local study, these results may present limitations when applied to the reality of the caregivers of children and adolescents with chronic conditions who live in other locations.

\section{$\square$ REFERENCES}

1. Mendes EV. Interview: the chronic conditions approach by the Unified Health System. Cienc Saúde Coletiva. 2018;23(2):431-5. doi: https://doi.org/10.1590/ 141381232018232.16152017

2. Ichikawa CRF, Santos SSC, Bousso RS, Sampaio PSS. The family management of children with chronic conditions according to Edgar Morin's complexity theory. Rev Enferm Cent-Oeste Min. 2018:8:e1276. doi: https://doi.org/10.19175/ recom.v8i0.1276

3. Lyra FMP, Souza ACOA, Alexandre ACS, Santos MRFASB, Silva FKB, Amorim LM. Family coping: living with the child affected by chronic disease. Rev Enferm UFPE online. 2016 [cited 2019 Aug 20];10(8):2790-800. Available from: https:// periodicos.ufpe.br/revistas/revistaenfermagem/article/view/11345/13058

4. Alves SP, Bueno D. 0 perfil dos cuidadores de pacientes pediátricos com fibrose cística. Cienc Saúde Coletiva. 2018;23(5):1451-7. doi: https://doi.org/10.1590/ 141381232018235.18222016

5. Lise F, Schwartz E, Milbrath VM, Santos BP, Feijó AM. Children with chronic renal failure on conservative treatment: adaptation process of the caregiver-mother. Ciênc Cuid Saúde. 2017;16(2). doi: https://doi.org/10.4025/cienccuidsaude. v16i2.33711

6. Freitas GL, Sena RR, Silva JCF, Castro FFS. Rehabilitation of children and adolescents with myelomeningocele: the daily life of motherscaregivers. Rev Gaúcha Enferm. 2016;37(4):e60310. doi: https://doi. org/10.1590/1983-1447.2016.04.60310

7. Palma E, Deatrick JA, Hobbie WL, Ogle SK, Kobayashi K, Maldonado L. Maternal caregiving demands for adolescent and young adult survivors of pediatric brain tumors. Oncol Nurs Forum. 2015;42(3):222-9. doi: https://doi.org/10.1188/15. ONF.222-229 
8. Barbosa TA, Reis KMN, Lomba GO, Alves GV, Braga PP. Supportnetwork and social support for children with special health care need. Rev Rene. 2016;17(1):60-6. doi: https://doi.org/10.15253/2175-6783.2016000100009

9. Reis KMN, Alves GV, Barbosa TA, Lomba GO, Braga PP. A vivência da família no cuidado domiciliar à criança com necessidades especiais de saúde. Cienc Enferm. 2017;23(1):45-55. doi: https://doi.org/10.4067/S0717-95532017000100045

10. SalvadorMS, Gomes GC,OliveiraPK, GomesVL0,BusanelloJ, XavierDM. Strategies of families in the care of children with chronic diseases. Texto Contexto Enferm. 2015;24(3):662-9. doi: https://doi.org/10.1590/0104-07072015000300014

11. Borsoi S, Scheidt IV, Cordeiro GR, Mascarenhas LPG. Análise da qualidade de vida em cuidadores de crianças e adolescentes com diabetes tipo 1. Multitemas. 2018;23(55):25-39. doi: https://doi.org/10.20435/multi.v23i55.1743

12. Vanz AP, Félix TM, Rocha NS, Schwartz IV. Quality of life in caregivers of children and adolescents with Osteogenesis Imperfecta. Health Qual Life Outcomes. 2015;13:41. doi: https://doi.org/10.1186/s12955-015-0226-4

13. Roncada C, Dias CP, Goecks S, Cidade SEF, Pitrez PMC. Usefulness of the WHOQOLBREF questionnaire in assessing the quality of life of parents of children with asthma. Rev Paul Pediatr. 2015;33(3):267-73. doi: https://doi. org/10.1016/j.rpped.2015.01.007

14. Okido ACC, Cunha ST, Neves ET, Dupas G, Lima RAG. Technology-dependent children and the demand for pharmaceutical care. Rev Bras Enferm. 2016;69(4):671-7. doi: https://doi.org/10.1590/0034-7167.2016690415i

15. Araújo YB. Sistema de Informação de Crianças e Adolescentes com Doença Crônica (SICADC): uma ferramenta de apoio à decisão [tese]. João Pessoa (PB): Universidade Federal da Paraíba; 2017 [cited 2019 Jun 12]. Available from: https://sig-arq.ufpb.br/arquivos/20171880885bd5473637d5d086e8753c/ TESE_YANA_BAUDUIN 0_DE_ARAUJ0.pdf
16. Fleck MPA, Louzada S, Xavier M, Chachamovich E, Vieira G, Santos L, et al. Aplicação da versão em português do instrumento abreviado de avaliação da qualidade de vida "WHOQ0L-bref”. Rev Saude Publica. 2000;34(2):178-83. doi: https://doi.org/10.1590/S0034-89102000000200012

17. Reis MS, Silva RDS, Amorim MLC, Lopes KAT, Corrêa LS, Leão DP. Avaliação da qualidade de vida de cuidadores de pessoas com deficiência física e intelectual: um estudo com WHOQOL-Bref. Rev Bras Prescr Fisiol Exerc. 2017 [cited 2019 Jun 13];11(67):399-404. Available from: http://www.rbpfex.com.br/index. php/rbpfex/article/view/1160/931

18. Rocha RS, Pinheiro LP, Oriá MOB, Ximenes LB, Pinheiro AKB, Aquino PS. Social determinants of health and quality of life of caregivers of children with cancer. Rev Gaúcha Enferm. 2016;37(3):e57954. doi: https://doi.org/10.1590/198314 47.2016.03.57954

19. Silva MEA, Moura FM, Albuquerque TM, Reichert APS, Collet N. Network and social support in children with chronic diseases: understanding the child's perception. Texto Contexto Enferm. 2017;26(1):e6980015. doi: https://doi.org /10.1590/010407072017006980015

20. Barros ALO, Barros A0, Barros GLM, Santos MTBR. Burden of caregivers of children and adolescents with Down Syndrome. Cienc Saúde Coletiva. 2017;22(11):362534. doi: https://doi.org/10.1590/1413-812320172211.31102016

21. Freitas GL, Faleiros F, Silva KL. Experience of families and the cost in the care of children and adolescents with myelomeningocele. Rev Enferm Cent-Oeste Min. 2019;9:e3282. doi: https://doi.org/10.19175/recom.v9i0.3282 
Cardoso ELS, Santos SR, Araújo YB, Neves NTAT, Nascimento JA

\section{- Acknowledgment:}

To CAPES, for the funding.

\section{- Authorship contributions:}

Conceptualization - Érika Leite da Silva Cardoso.

Data selection - Érika Leite da Silva Cardoso, Yana

Balduíno de Araújo and Nívea Trindade de Araújo

Tiburtino Neves

Formal analysis - Érika Leite da Silva Cardoso and João

Agnaldo do Nascimento.

Investigation - Érika Leite da Silva Cardoso.

Methodology - Érika Leite da Silva Cardoso and Sérgio

Ribeiro dos Santos.

Project administration - Érika Leite da Silva Cardoso.

Resources - Érika Leite da Silva Cardoso.

Supervision - Sérgio Ribeiro dos Santos.

Visualization - Érika Leite da Silva Cardoso.

Writing - original draft - Érika Leite da Silva Cardoso.

Writing - review and edition - Sérgio Ribeiro dos Santos,

Yana Balduíno de Araújo and Nívea Trindade de Araújo

Tiburtino Neves.

- Corresponding author:

Érika Leite da Silva Cardoso

E-mail: erikaleiteenf@gmail.com

Associate editor:

Jéssica Machado Teles

Editor-in-chief:

Maria da Graça Oliveira Crossetti 